\title{
The Biblical Mandate and Implications for the Ministry to the Deaf People
}

\author{
Lulama Tshuma \\ Adventist University of Africa, Zimbabwe \\ DOI: https://dx.doi.org/10.47772/IJRISS.2021.5329
}

\begin{abstract}
Despite attempts by governments and church organizations to formally educate and empower the deaf people, their lives still remain unsatisfactory. They also seem to suffer marginalization from the larger hearing society because of their communication barrier. In His Ministry of the deaf people Jesus appears to foster inclusivity and their empowerment to face life's challenges. Little research has been undertaken on how deaf ministry can be improved as to capacitate the deaf in the communities they livein. This paper exegeted Mark 7:31-37, 9:14-27 and Luke 11:14-26 in light of some isolated texts that make reference to deafness in the Bible with the object of helping in forging out relevant interventions that can answer out the gaps in the deaf ministry. Although these Bible texts were not originally written to inform deaf ministry, there are principles in them that can shape, influence and direct it. In Mark 7:31-37 Jesus used more outward actions than usual in communication with the deaf-mute. The deaf people that Jesus met were healed even though not all people with disabilities were healed during Jesus' time. Jesus'actions and gestures when healing the deaf seem to encourage integration of the deaf people and their empowerment for survival in the mainstream hearing community. Mark 7:31-37, 9:14-27 and Luke 11:14-26 were chosen texts for exegesis because they are the only lengthy narratives that describe the healing of the deaf in the Bible. The others are single text references to deafness scattered in several books of the Bible. The study made use of narratives, Bible commentaries and Ellen White wrings as the main source data for the study. The study recommends that the deaf ministry must integrate the deaf people to the mainstream hearing community through programs that domesticate Sign Language (SL) in the larger community. Furthermore, the community must ensure that they empower the deaf people spiritually and economically so that they cease to see themselves as objects of charity but independent beings who can single handedly face life's challenges.
\end{abstract}

Keywords: Deaf Ministry, sign language, mogilalon, disability, models of disability.

\section{INTRODUCTION}

$\mathrm{T}$ he passages in question (Mark 7:31-37, 9:14-27 and Luke 11:14-26) were examined in thelight of the biblical texts that make reference to deafness and disabilities in general. The three passages were selected for consideration because they are the only ones in the Bible that gives lengthy narratives of how Jesus treated the deaf and dumb people. The rest are mere references scattered randomly in other books of the Bible. The organization of the paper a brief background of the study, models of disability, the exegesis of the selected texts, findings and discussions, conclusions and recommendations.

\section{Background of the Study}

Despite attempts by governments and church organizations to formally educate and empower the deaf people, their lives remain unsatisfactory. They also seem to suffer marginalization from the larger hearing society because of their communication barrier. In His Ministry of the deaf people Jesus appears to foster inclusivity and their empowerment to face life's challenges.

\section{Disability in the Bible}

Fritzon, (2014) observes that the Bible does not have anumbrella word in Greek or Hebrew which is an equivalent for disability. In the Bible disability appears to be viewed as a disease. The most common diseases mentioned in the Bible are blindness, deafness, dumbness, leprosy, and paralysis. Luke in Luke 7:22clusters these together when he records Jesus as saying that "...the blind receive sight, the lame walk, those who have leprosy are cleansed, the deaf hear, the dead are raised, and the good news is proclaimed to the poor." Disability in the Bible also appears to refer to functional impairments, social experiences and injuries.

The Bible does not mention the natural causes of disability, although during New Testament era a significant number of disabilities seem to have been attributed to demon possession (Mark 7; 31-37, 9:14-27). According to the Old Testament, it appears as if God brings disability as punishment for transgressions for sin or as an expression of His wrath for people's disobedience. The Bible portrays disability as a curse and as a result of disobedience, unbelief, and ignorance (Deut. 28:28-29).

Owusu-Antwi(2011), notes that a demoniac can be physically or mentally affected. A demon could inflict the victim with nudity (Luke 8:35), seizures (Mark 9:18), dumbness (Matthew 12:22) and deafness (Mark 9:25). He further explains that the Bible differentiates between demonization and sickness. For instance, Mark 1:34states that "Jesus healed many who had various diseases. He also drove out many demons" (NIV). In the three passages (Mark 7:31-37, 9:14-27, Luke 11:25) it appears that deafness and muteness were caused by demon possession. The Bible itself affirms that the three people who mentioned above were demon possessed. This is further confirmed by the cure of their deafness at the exorcism of the 
demons. Those engaged in deaf ministry may benefit from inquiry into the cause, onset and duration of deafness in order to render relevant service to a deaf person. They may also acquire information about the nature and cause of deafness of those that they minister to, so as to render the best possible assistance. If exorcism solves the problem, then it was probably not a pathology. If medicine helps alleviate the problem, it was not demonization as demons cannot be exorcised by drugs. Deaf ministry must be born out of an understanding of the nature of the deaf person's challenges if it is to meet their felt needs.

\section{The Perfect Environment before the fall}

The original perfect environment before the fall of man had no deaf people as evidenced by the fact that after creation, God "saw all that he had made, and it was very good" (Gen. $1: 31)$. The writer repeatedly mentions that "....and God saw that it was good" (Gen 1:10, 12, 18, 21, and 25). Adam and Eve, the only beings who existed, heard the voice of God and hid from his presence (Gen.3:10). Deafness merely appeared sometime after the fall of mankind as a result of the sin curse. There is no record in the Old Testament of any one who was ever healed from deafness. However, its reality and existence is acknowledged in Exod. 4:11, Psalm 94:9; Lev 19:14 and Psalm 28:1. This assertion is further confirmed by several promises in the Old Testament of the healing of the deaf during the Messianic age (Isa. 32:3; 35:5-6) and its ultimate eradication at the coming of Christ (Rev. 22:3).

Disability according to World Health Organization (WHO) (2019) is defined as
A condition or function judged to be significantly impaired relative to the usual standard of an individual or group. The term is used to refer to individual functioning, including physical impairment, sensory impairment, cognitive impairment, intellectual impairment mental illness, and various types of chronic disease.

Disability may affect organs or body parts, and a person's participation in areas of life. Some disabilities are visible whereas others are invisible. They may affect a person's vision, learning, communication, movement, and mental health. In many cultural settings, avoidance and stigma from the general populaceare the dominating reactions.

Furthermore, while there are many forms of disability this paper is confined to hearing impairment or deafness. In this paper, deafness and hearing impairment will be used interchangeably. The World Health Organization (WHO) defines hearing impairment as a complete or partial loss of hearing in one or both ears. The impairment can be mild, moderate, severe or profound. The degrees of hearing loss are usually not described in the Bible.

The Anthropologist Devlieger(2002) distinguishes four predominant models by which impairment and disability can be approached: the moral, medical, social, and cultural. These are the four ways through which people understand disability. This paper discusses them within the context of deafness. The research will analyze each in light of the Biblical view of disabilities. Finally, the paper will discuss the mandate and implications of exegeted Bible passages on deaf ministry.

\section{The Religious Model of Disability}

The religious model attributes the cause of impairment and disability to God. According to this model disability should be regarded as a punishment from God for a particular sin or sins that may have been committed by the person with disability. Retief and Letsosa(2018)say that some believe disability is received by some as a test of faith and if one does not experience physical healing of their disability it is regarded as lack of faith in God. Some are tempted to think that it is probably due to a lack of faith on their part to remain disabled when others testify to having been delivered.

While God removes deafness as is the case in the three miracles of Mark 7:31-37, 9:14-27 and Luke 11:14-28 there were instances where He would choose not to cure. God is omnipotent, yet at times He does not remove some disabilities as evidenced by Paul's thorn in the flesh that never healed ( 2 Cor. 12:7-9). Paul left Trophimus ill at Miletus (2Tim.4:20). He must have prayed for him, but no healing occurred. Throughout its history, the church seems to have ministered to the deaf in their deafness.

However, Smith (2019)et. al. define healing as:

\section{... a holistic, transformative process of repair and recovery in mind, body, and spirit resulting in positive change, finding meaning, and movement toward self-realization of wholeness, regardless of the presenceor absence of disease.}

The religious model seems to concur with the biblical model in that it sees disability as a disease yet on the contrary the Bible asserts that healing is realized regardless of the presence or absence of a disease or disability. Mephibosheth (2 Samuel 9:1-13) and Paul (2Corinthians 12:1-13) lived with their disabilities for the whole of their lives yet they experienced healing.

\section{The Medical Model of Disability}

The medical model sees disability as a disease andits focus is on the physical condition of the person with disability. Some parts of the Bible seem to classify disabilities including deafness with diseases as seen in Jesus' healing ministry (Luke 7:21-22). From the mid-1800s onwards, the medical model of disability began to gradually replace the moral model in lieu of significant advances in the field of medical science. This would explain why the special schools of the deaf came into being. On the other hand, Moyo(2019) observes that the disabled person under the medical model becomes a lifetime patient who hands over the control of their own life to health care professionals who will perpetually try to cure the impairment. Such an attitude disempowers since 
the person does not see themselves as complete and totally independent human being. As already noted, the Bible seems to point out that if a disability is not removed the disabled must be empowered to live with it.

\section{The Social Model of Disability}

The social model of disability which emerged in the1970s, defines disability as a social construct. In this case, the social model of disability argues that disability is something that is created by barriers that exist within the society. Barnes, Mercer, \& Shakespeare, (2010) argue that it is society 'which disables people with impairments, and therefore any meaningful solution must be directed at societal change rather than individual adjustment and rehabilitation. While the medical model is narrowly confined to the medical curing of impairment, the social model advocates for the transformation of community and society. The social model of disability seems to harmonize with the Biblical model in the sense that it is social transformation. When dealing with disability the able bodied must be helped to change their attitudes to people with disabilities.

\section{The Cultural Model of Disability}

The cultural model sees disability as culture. According to Megan, (2002)this model insists that deaf people are not disabled but they are different. Deafness accordingly is not a pathology that needs fixing. The deaf people are a minority group who communicate through their signs which construct their unique language known as sign language. The model that sees disability as normal culture that does not need to be fixed is not in harmony with the Bible. As already noted from the text that have been exegeted, Jesus on several occasions healed the deaf and other disabilities.

These are the predominant disability models that have influenced people's understanding of disability. This understanding has a bearing on the way society treats the people with disability and the deaf people are not exempt from attitudes and treatment that are born out of these models. These disability models also provide the basis for systematic approaches to understanding the causes and context of disability. They are also tools for defining impairment and ultimately provide the basis to devise strategies for meeting the needs of individuals with disabilities

\section{FINDINGS AND DISCUSSIONS}

\section{Hearing to Initiate the Deaf Ministry}

The biblical narratives (Mark 7:32; 9:17) seem to suggest that the hearing community should initiate a ministry programmes for the deaf. The Bible perspective sees deafness as a disease. It subscribes to the Medical Model of disability according to which deafness must be fixed. This is why on both incidents the deaf and dumb are brought to Jesus for healing.
Mark becomes the only writer in the New Testament who used the term "Mogilalos" in connection with deafness. In the Bible, the term "mogilalos" is used only twice in Mark 7:32 and in the LXX where it occurs in Isaiah 35:6. While both Matthew and Luke in their narratives of the Beelzebub controversy refer to the demon harassed man as "mute" prior to his healing they have not used the term "mogilalos." Edwards (2002)believes that Mark chose to use this term because to him it signalled the eschatological arrival of the day of the Lord. He further insists that Jesus's healing of this particular mogilalos in the Decapolis becomes the first fruit of the fulfilment of Isaiah 35:6. ${ }^{1}$ It may well be that Mark used the term as a way of showing that the healing of the deaf mute in Mark 7:32 marked the beginning of the Messianic age predicted in Isaiah 35:6. Since one of Mark's interests was the articulation of the "Messianic Secret" motif, he chose to use the exact term found in Isaiah's prophesy. This signalled that salvation was also being ushered to the Gentiles. The deaf received it through Jesus who is God's eschatological redeemer from Zion. Mark the gospel writer may have used the exact term that is used by the prophet Isaiah (Isaiah 35:6) because he saw the healing of the deaf-mute (Mark 7:32-37) as a fulfilment of prophesy and a call to revive deaf ministry.

\section{The Need to Improve Communication}

The healing of the deaf seems to be a call to help the deaf work on improving their communication skills. Taylor(1989) explains that mogilalon means the young man had an impediment in his speech. "Mogilalon" stems from "Mogis" meaning "with difficulty" and "laleo" not absolutely dumb. Barclay W. (1969)also notes that deafness and muteness are closely linked because one with hearing impairment will hardly develop oral skills. In both Mark 7:32-37 and Mark 9:14-30 muteness and deafness seem to be closely associated and caused by demon possession. It was after the deliverance from demons that this man was able to speak clearly (Mark7:32-37). He must have been partially deaf and dumb.

The ability to communicate may differ from one deaf person to another. The man in Mark 7:32-37 could speak but had a serious speech impediment. Oral speech can be impossible to the deaf and dumb but their communication skills could be improved through teaching them oral language in its written form or signed oral language (or signed English).

The deaf and dumb were enabled to speak and hear after their healing by Jesus. The deaf-mute in Mark 7:31-37 spoke clearly only after delivery from demons. The mute in Luke 11 also spoke after his deliverance, yet he was never said to have been deaf. The young man brought by his father had a deaf and dumb spirit (Mark9:17) and when Jesus rebuked it he said, “....you dumb and deaf spirit..." (Mark 9:25). This would suggest that the young man was deaf and dumb. The

"Mogilalon" A Call For Revival of Deaf Ministry 
father told Jesus that his son was possessed by a spirit that had robbed him of speech (Mark 9:17). The restoration of speech must have given them access and benefits that had been hindered by the communication barriers resulting from deafness and muteness. Consequently, they could witness and transact business within their community. It is the responsibility of the hearing to help the deaf improve their communication skills. Their ability to communicate empowers them to transact business. The deaf can be taught formal Sign Language and written oral language.

\section{First, Jesus took the man aside before healing him.}

The avoidance of publicity when performing miracles could have been in harmony with the Messianic secret motif in Mark's gospel. He would sometimes call aside those who needed help (Mark 5:37, 40, 43; 8:23) or order them not to tell anyone after the miracle had been performed (Mark1:25, 34, $44 ; 8: 30)$. This was a usual way of healing especially among the Jews who had a misconception of His Messiahship but in this case, he was in the midst of gentiles who had no expectation of a coming Messiah.

According to Nichol (1980), the methodology Jesus used in healing could be interpreted as a form of magic similar to the incantations of heathen miracle workers.Jesus' cure of the deaf-mute meant more than fixing a disability but to lead to the deliverance of the man from sin, hence taking the man aside was to prevent distraction of people's attention from the sole purpose of His mission. He possibly did not want these gentiles to be drawn to him merely for healing. His miracles were meant to arouse faith and to lead to deliverance from sin and eternal life which is man's greatest need.

Furthermore, Jesus took the man aside by himself so that he was away from the crowd. He probably wanted the deaf mute to feel more at ease by avoiding the man becoming an object for satisfying the curiosity of the crowd (Mark 7:32-37). He probably wanted the deaf mute to feel more at ease by avoiding the man becoming an object for satisfying the curiosity of the crowd (Mark 7:32-37). However, Barclay (1969) observes that among gentiles there was danger of Jesus being portrayed as a mere miracle working figure and they could have flocked to him to satisfy their curiosity and to be relieved from ailments. Among the Jews the public healing would excite their Messianic expectation which would result in His premature death. On the other hand, Edwards (2002) asserts that Jesus removed the man from the crowd to signify that he was not simply a problem but a unique individual. If that is the case such an activity must have served to restore the deaf man's dignity in a community that segregated and stigmatised deaf people. The very fact that Jesus ministered to the deaf in such a way as to avoid being misinterpreted is a summons to conduct a deaf ministry that would go beyond meeting the physical needs of the deaf. While Jesus would isolate those that he healed, it is not only when he healed the deaf that he isolated those that he healed but when he dealt with other ailments
Jesus' activities in healing the deaf were meant to educate people to be motivated by the right reasons in doing this deaf ministry. He was not merely satisfying their curiosity nor was He arousing Jewish Messianic expectations that would lead to His premature death. Jesus did everything possible to develop faith and trust in God to those who witnessed his miracles.

Jesus called the man away from the crowd possibly to secure his undivided attention.

\section{Jesus' Actions Call for Inclusivity of the Deaf}

Although during Bible era both in the Old and New Testaments, the deaf suffered marginalization and exclusion, Jesus's actions in Mark 7:32-37, 9:14-27 foster inclusivity of the deaf people. Mark does not only use the exact word in Isaiah 35:6 but also Jesus' actions in Mark 7:31-37 portrays acceptance of the deaf-mute. Jesus took him aside to give him an individualised personal special treatment. He treated the deaf man with dignity and respect.

Some imagery led to stigmatization and exclusivism. There were time when in the Bible Israel's disobedience was equated with disability (Isaiah 43:8). According to "The Dictionary of Biblical Imagery" the metaphoric use of disability in the Bible seems to reinforce the view that links disability with disobedience to God. Deafness in some texts is compared to unwillingness to obey God. (Isaiah 42:18-20, Matthew 13:13.)

The inclusivity of people with disabilities is also seen in God's plan for the restoration of the Israelites. God assured Israel in Babylon that they would return back to Jerusalem. Isaiah 35:5-6 outlines the joyous return of the liberated Israelites: "Then will the eyes of the blind be opened and the ears of the deaf unstopped..." He further adds, "In that day the deaf will hear the words of the scroll..." It must be noted that the deaf are specifically mention amongst the various people with disabilities in the Israelite remnant who are returnees from the Babylonian captivity.

\section{Helping the Deaf Understand the Gospel}

Watts (1987) observes that the reference to the blind and deaf is an allusion to another motif in the vision of Isaiah 35. They are the symbolism of a people who cannot understand the call of God to participate in his work. Now God's unmistakable intervention on Zion's behalf gives a sign that even the blind and deaf should understand. This is to say that this must not only be a summons to revive deaf ministry but itis symbolic of the opening of ears and understanding of the gospel by those blinkered by tradition.

\section{The Call for Empowerment of the Deaf}

The removal of the communication limitations empowered the deaf mute (Mark 7:31-37) to become a witness for Jesus at Decapolis just like Legion. White (1909) asserts that the man then"published abroad the story of his cure." That Jesus was concerned about the usefulness of the lives of those that $\mathrm{He}$ healed is also noticeable in the command, "come out of Him and enter no more into him" (Mark 9:25). Jesus did not want 
the healed lad who had been deaf and dumb to relapse to his former life that had rendered him useless. Jesus's ministry would not end only with permanent restoration of hearing and speech but to lead to a life of service to others.

Furthermore, the parable of the empty house that comes after the Beelzebub controversy, seems to emphasise that one who is served must be empowered for service (Luke 11:14-26). This healed man was probably also deaf since dumbness and deafness usually went together as noted in Mark 7:32-37 and Mark 9:14-27. In this parable, Jesus asserts that when demons return to find the former demoniac's life unoccupied with a life of service then it calls seven other demons "and the last state of that man becomes worse than the first." (Luke 11:25, 26). In this parable Jesus taught that those who are delivered from demons must be empowered to occupy themselves with a life of service to avoid relapsing to their former condition. (Luke 11:25).In concurrence Barclay (1969) comments that the best way to deal with evil is to replace it with good.

Luke 11:20 says "But if I drive out demons by the finger of God, then the kingdom of God has come upon you." The defeat of demons would imply that a greater and more powerful kingdom than that of demons had come as evidenced by the deliverance of the possessed. Luke also saw a gradual retreat and defeat of the demonic kingdom at the launch and the advancement of Christ's ministry. This subjugation of demons and restoration of hearing and speech marked the dawning of the Messianic age which would culminate in the total eradication of the curse of sin and disabilities at the second

Coming of Christ. (Rev. 21:3)

\section{Jesus' Actionsand their Implication}

Henrys (1991) observes that in Mark's narrative of the deaf mute (Mark 7:31-37), Jesus used more outward actions in doing the cure than usual. The miracle involved six actions: taking the man aside, thrusting His fingers into the man's ears, touching the man's tongue, spitting, looking up and sighing and saying, "Be opened". While one may be tempted to thing Jesus' actions were normal activities that would naturally accompany oral speech, it is not an accident that He used more outward action than in other miracles. Actions communicate to the deaf people more than they do to the hearing because the former are sight oriented. While Jesus was probably not using sign language His actions must have been an effective form of communication to the deaf-mute. Chimedza et al. (2007) define Sign Language (SL) as "a manual communication where hand plus arm shapes, positions and movements are used to form signs in the language." Unlike oral language it is visual, manual and comprising hand plus arm shape as a means of communication. The hearingimpaired use their eyes for both hearing and seeing. They must look at the actions of people they communicate with to decipher what they say. In Jesus's activities there is contextualization as a means to reach out to the deaf person. He understood the most effective means of reaching this deafmute. Keller (2016) argues that, "sound contextualization means translating and adapting the communication and ministry of the gospel to a particular culture without compromising the essence and particulars of the Gospel itself." Consequently, to the hearing $\mathrm{He}$ used oral language and to the hearing impaired he used action. Those who minister to the deaf must bear in mind that these people are sight oriented. They will understand manual language not oral one since their hearing is impaired. Even when one who attempts to communicate with them has not mastered Sign Language, they can read what they attempt to communicate as they look at their gestures.

Sighing and Looking up to Heaven

In dealing with the deaf, Jesus seems to have used gestures to reinforce His communication and to develop trust in God. Some have associated this gesture with prayer because in the following passages such is closely linked to prayer (Exod. 2:24, 6:5, Judges 2:18). According to Taylor, (1989) Jesus's actions in this healing were common techniques of both Greeks and Jewish healers that naturally created an atmosphere of expectation. In consequence, Jesus's actions must have aroused the faith of the Decapolitan since His actions resembled those of the Gentile healers. Sighing and looking up which would be associated with prayer, would naturally draw attention to God as the source of power hence helping the deaf to put his trust in God. Jesus' gesture was an upward focus driven by prayer. Sighing and looking up which would be associated with prayer, as that would naturally draw attention to God as the source of power hence helping the deaf to put his trust in God and Jesus' gesture in this sense was an upward focus driven by prayer.

However, in this model the deaf people are not involved in ministry since everything done during services is hearer centered. Through the use of actions and gestures Jesus entered the world of the deaf to help him develop a personal faith relationship with God instead of remaining a passive recipient of God's blessings.

\section{Touching the Deaf Mute}

Jesus procedure of healing may have been appropriate to the deaf. The use of ballo which means "to throw, to thrust" suggests that he put that one finger of His right hand into one ear and one finger of His left hand into the other(Wuest (1950). He spat and touched his tongue. He further explains that the deaf person could not hear anything our Lord could say and He took this as a means of arresting his attention and encouraging his faith. However, Mark does define the meaning of some terms like "Ephphata" "be opened" to his Gentile audience he gives no explanation of the particular meaning of the acts to the first century person. His actions are not interpreted probably because his Gentile audience was familiar with them. Wuest's (1950) attempt to explain that the meaning of Jesus acts as He sought to heal the deaf man 
appear commendable because if one is deaf the only way to communicate with them is through touch and gestures. Barclay (1969) argues that the acts of Jesus were meant to show the tenderest considerations for the feelings of the deaf $\operatorname{man}^{3}$. Therefore, effective ministry of the deaf will call for a mastery of the best gestures and signs that communicate love, tolerance and acceptance to this culture whose language is predominantly manual. Jesus would mingle and touch them as a means or as a way of acceptance. Jesus also touched the solitary leper (Mark 1:35-38; Luke 4:42, 43)as a way of acceptance and social mingling at all levels.

Jesus thrust His fingers into the man's ears, spit and touched the man's tongue. Edwards (2002) understands the touching of the man by Jesus to repeat his radical identification with the needy and the ritually unclean. Such a view is further consolidated by the following texts where Jesus acted in the same manner to communicate acceptance (Mark1:31, 1:41, $3: 5,5: 33,41$; and 6:56). According to Barclay (1969) physical contact must have expressed compassion and acceptance, whereas Wuest (1950) sees touch as a way of arresting his attention and encouraging faith. Since the man was deaf, touching him could have been the most effective means of drawing attention. Concerning the use of saliva, Sweet (1977) explains that the deaf mute saw it as remedial and possibly to the Decapolitan it appealed more strongly than any other symbol. He further argues that the faith of this man needed all the support that visible signs could afford. He further viewed the use of the Lord's fingers and saliva to emphasise the truth that the healing power proceeded from Christ's person. Although some would associate Jesus's gestures with those that normally accompany oral speech in the hearing community, it would appear that they were an intentional means of communication to arouse faith, to communicate compassion to the segregated, to show acceptance and finally to direct attention to God as the source of healing power. In communicating with the deaf, Jesus seems to have taken into cognisance the fact that the deaf people are sight oriented. It is a visually interactive language that uses a combination of hand motions, body gestures, and facial expressions that appeals to the deaf. It was this language that would lead the deaf to an understanding of God and hence to be saved. It must be noted that a warm greeting is not enough as there should be mingling and touching that communicates more intimate relations.

The hearing people are to initiate the ministry to the deaf. This is suggested by the fact that the deaf-mute (Mark 7:32-37) was brought to Jesus by some unmentioned men and the lad who was deaf and dumb was brought to Jesus by his father. However, references such as "when you give a banquet, invite the poor, the crippled, the lame, the blind, you will be blessed" (Luke14:13) have led some to believe that the Bible justifies the treatment of the disabled as charity cases. The ministry to the deaf should lead to their integration into the mainstream hearing community and empowerment for service.

\section{The Ministry to the Deaf and the Great Commission}

The disciples were commissioned to "make disciples of all nations" (Mat.28:19-20). The term "all nations" in the Interlinear Greek-English New Testament(1870) is rendered "panta ta ethnee" which may also be interpreted as referring to all people groups. The concept of people groups seems to be captured also in Revelation 14:6-7 where the angel preaches to "those who live on the earth - to every nation, tribe, language and people.'For Winter, (2009)a people group is a group of individuals that share a common affinity with each other based on language, religion, ethnicity, residence, occupation, class or caste, situation, or a combination of these. ${ }^{4}$ However, if seen from a missionary perspective, the element of disseminating the gospel must be added. For this reason Bruce and Winter(2009) argue that a people's group comes to be defined as a social group where the gospel can be proclaimed without hindrances of understanding or acceptance.Therefore, the deaf are not a nationality but a people group within different nations who are held together by their unique sign language. The angel in Revelation 14:6 proclaims the gospel in different languages hence, the deaf are to be reached while taking into cognisance their culture and unique sign language. The deaf people are therefore one among many people groups that must be reached with the gospel. The deaf people are therefore one among many people groups that must be reached with the gospel. Sign Language is key in this regard.

\section{The Biblical Model of Deaf Ministry}

The Deaf Ministry must be shaped, influenced and informed by principles derived from the Bible. The Bible seems to favour an integrated ministry in which the Deaf and hearing worship together making it a ministry with, and not a ministry to the deaf. When the deaf people become church members they must be helped to discover their spiritual gifts and to find their way into the ministry of the church. The deaf-mute was brought to Jesus for healing and must later have been integrated into the community. A balanced deaf ministry is not only deaf-friendly but also affords them the opportunity for growth through empowerment programmes. Paul, as already noted, had a disability though it was not deafness yet he used his spiritual gifts to minister to others.

\section{CONCLUSION}

The findings reveal that the Bible sees deafness as one of the disabilities or diseases that came as a result of the sin curse. The Old Testament has the promises of the healing of disabilities including deafness during the Messianic age and its total eradication at the second coming of Christ(Revelation 
21:3). Although, the Bible does not give the natural cause of deafness, the three passages that have been exegeted in the New Testament seem to suggest that deafness is caused by demon possession. The deaf and dumb healed at the exorcism of the demons that harassed them. (Mark 7:32-37; 9:14-27) When healing the deaf-mute in Mark 7:31-37 Jesus used more gestures and actions than in other healing miracles in the gospels. He communicated this way to contextualize His message and to arouse the faith of the deaf person and their trust in God. While some people with disabilities were cured at their healing from disability others did not have their disabilities removed at their healing. During Bible times not all disabilities were cured. A few among many whose disabilities were not cured are Mephibosheth (2 Samuel 9:113) and Paul the apostle (2Corinthians 12:7-9). Those whose deafness is never removed must be empowered to live with it. These deaf people also have spiritual gifts and talents that they can beused to serve others. They must not see themselves as objects of charity but as service providers together with the hearing people.

\section{RECOMMENDATIONS}

In line with the study carried out on exegeted biblical passages including isolated texts on deafness which are scattered in the Bible, it is therefore recommended that:

The hearing people should initiate the deaf ministry through familiarizing with deaf culture and learning to use Sign Language so that they can easily socialize and be involved in ministry with deaf people. The communities be educated and trained on the communication needs of deaf persons. Furthermore, the mainstream hearing communities should be educated to avoid actions and language that fosters marginalization and exclusion of the deaf people.

The deaf to should be empowered economically so that they cease to see themselves as objects of charity but be involved in ministry as service providers to other needy people. They should also be elected to leadership positions in society so that they are involved in decision making. This would facilitate their integration into the mainstream hearing community. The deaf ministry must do three things namely empowerment, reducing communication gap, and integrating them into the mainstream hearing community.

\section{REFERENCES}

[1] Barclay, W. (1965).The Gospel of Mark. Edinburgh: The Saint Andrews Press.

[2] Barclay, W. (1975).The Gospel of Matthew. Philadelphia: The Westminster Press.

[3] Barnes, C.; Mercer, G.; \& Shakespeare, T. (1999). Exploring disability: A Sociological Introduction. Cambridge: Polity Press.

[4] Berry G. R., (1870).The Interlinear Greek-English New Testament. Oregon: The Eye Opener Publishers.

[5] Bucklew, J.R (2014). "Breaking the silence" Mission Frontiers Issue 36:1, January/February.

[6] Bruce, Koch A., and Winter, Ralph D.(2009). Finishing the Task: The Unreached Peoples Challenge. In Perspectives on the World Christian Movement: A Reader, 4th ed., edited by Steve C.
Hawthorne and Ralph D. Winter, Pasadena, CA: William Carey Library

[7] Chimedza, R., Sithole, C.Z. and Rinashe, (2007) Zimbabwe National Sign Language Dictionary. Harare, SPS and SNE, UNICEF.

[8] Devlieger,P. (2002)."Handicap, kosmologieen revalidate," paper presented for the Liliane Foundation and the Dutch Coalition on Disability and Development, Den Bosch, The Netherlands, November 29.

[9] Duriez, C. (2007).The Dictionary of Biblical Imagery. Edited by Douglas Penney and Daniel G. Reid . England :InterVarsity Press.

[10] Edwards R. J. (2002) The Gospel According to Mark. William B Eerdmans Publishing Company, Grand Rapids, Michigan.

[11] France, R. T. (2002). The Gospel of Mark: A Commentary on the Greek Text. William B. EerdmansPublishing Company Grand Rapids, Michigan.

[12] Fritzon A. (2014) "People With Disabilities in the Bible: Who are they and What Can weLearnFromThem?"Echos19(accessedMarch10,2014)http//www. wcc/whatipc/echos /echos-19-06.html

[13] Francis D. (1978). The Seventh-day Adventist Bible Commentary. Washington, D.C.: Review and Herald Publishing Association.

[14] George R. B. (1870)The Interlinear Greek-English New Testament(Oregon: The EyeOpener Publishers.

[15] Henry's, M. (1991) Commentary, on the Whole Bible complete and unabridged in onevolume,Grand Rapids, MI: Hendrickson Publishers.

[16] Hlatywayo, L., \& Ncube A. C. (2014) "The Extent to which Transitional Services PrepareDeaf Learners for Community Participation: the Zimbabwean Case," Zimbabwe Open University:108-113.www.iosrjournals.org.

[17] Hlatywayo, L., Hlatywayo, S. \&Mtezo, J.Z. (2014). The Employment of Deaf Persons: A Zimbabwean Employers Perspective, Disability Studies and Special Needs Education, Zimbabwe OpenUniversity,2014),37-43. Accessed 3September, 2019.

[18] Watts, J. D.W. (1987) Word Bible Commentary. Vol. 25 Word Books, Texas: Publisher WACO.

[19] J.R. Bucklew, (2014) "Breaking the silence" Mission Frontiers Issue 36:1, January/February.

[20] Keller, T. (2016) Loving the City: Doing Balanced Gospel Centered Ministry in Your City: Grand Rapids: Zondervan.

[21] Martin P. (1993). Word Biblical Commentary. Vol. 35b. Dallas ,Texas Word Books Publisher.

[22] Martin P. Ralph. Word Biblical Commentary Vol.40. 2 Corinthians. Nashville: Thomas Nelson, 1986.

[23] Megan, A. J., (2002) Centre of Disability Studies: University of Hawaii at Manoa, Disability Studies Quarterly: Spring: Vol. 22, No.2 p.51-60

[24] Moyo,A. (2019). Selected Aspects of the 2013 Zimbabwean Constitution and the Declaration of Rights. Raoul Wallenberg:DP Print Media.

[25] Mutshwanga,and Sithole.(2014) "Perceptions of People Who are Deaf on Sign Language Teaching and Communication by Hearing People," Greener Journal of Education and Training Studies vol 5No 2(2014): accessed 2017. Harare Urban, Zimbabwe.

[26] Owusu-Antwi,B. (2011) The Church, Culture and Spirits: Adventism in Africa, Kwabena Donkor, (editor) Biblical Research Institute Silver Spring,MD 20904.

[27] Patrick, D. (2002) "Handicap, kosmologieen revalidate," paper presented for The Liliane Foundation and the Dutch Coalition on Disability and Development, Den Bosch. $\quad$ (November 2002):81, The Netherlands, doi: 10.1016/j.socscimed.2007.01.008

[28] Marmo, R. and Rantoa. L. (2018).“Models of Disability: A Brief Review," Faculty of Theology, North-West University.

[29] Mutswanga, P. and Mapuranga, B.(2014)."Perceptions of 'Hearing' People on Sign Language Learning in Zimbabwe," Zimbabwe Open University (2014): accessed December 2017.www.arcjournals.org

[30] Horn,S. H. (1980)Seventh-day Adventist Bible Dictionary $(S D A B D)$, rev. ed. (1979), s.v.“Angel." 
[31] Smith, K. (2015) Healing: A Concept Analysis: Accessed on 11August

2019.,https://www.researchgate.net/publication/283904253.

[32] Swete, B. H. (1977) Commentary on Mark: The Greek Text. Grand Rapids, Kregel Publications: Michigan.

[33] The World Health Organization, Deafness and Hearing Loss, 1 March 2020

[34] The World Health Organization, Deafness and Hearing Loss, 20 March 2019.
[35] Taylor, V. (1989). The Word Studies in the New Testament Vol. 1. Grand Rapids: WMB Eerdmans Publishing Co., Michigan,.

[36] Vincent, M. R. (2002). The Word Studies in the New Testament, Vol. 1.Grand Rapids: WMB Eerdmans Publishing Co., Michigan,

[37] Vincent, M. (1989) The Word Studies in the New Testament Vol. 1, Grand Rapids: WMB Eerdmans Publishing Co., Michigan.

[38] White, E.G. (1909) The Desire of Ages. (Mountain View, CA; Pacific Press, 1909.

[39] Wuest, K. S.(1950) Mark: In the Greek New Testament, Volume 10, London: Pickering \& Ingis Limited. 